5. Addlakha R. Disability, sexuality and reproductive health in India: a training manual for professionals working with adolescents and young people with physical disabilities. New Delhi: MacArthur Foundation in India; 2005.70 pp

6. Addlakha R. Adolescents, youth with disabilities unable to access programmes targeting sexuality [Interview]. DNIS, Disability News and Information Service [Internet]. 2005 Sep 15 [cited 2009 Nov 24];3(18): about 3 screens. Available from: http://www.dnis.org/interview. php?issue_id $=18 \&$ volume_id=3\&interview_id=70\#maincontent Interview by Bhambhani M, Singh P.

7. Addlakha R. Gender, subjectivity and sexual identity: how young people with disabilities conceptualise the body, sex and marriage in urban India. New Delhi:Centre for Women's Development Studies. Occasional Paper Series.2007;46.31 p.

8. Addlakha R. How young people with disabilities conceptualise the body, sex and marriage in urban India: four case studies. Sexuality and disability. 2007 Sep;25(3):111-23.

9. Addlakha R. Healthy sex life for visually challenged women. In: A K Mittal ed. Handbook for women with visual impairment. New Delhi: All India Confederation of the Blind (Sponsored by Dr H E Schulze and Marga
Schulze Foundation, Germany);2008. p.60-7.

10. Addlakha R, Mandal S. Disability law in India: paradigm shift or evolving discourse? Econ Pol Wkly. 2009 Oct 10;44(41 and 42):62-8.

11. Das K. Desexualising her. Combat Law, the human rights magazine [Internet]. 2008 Jan- Feb [cited 2009 Nov 24]; 7(1). Available from: http:// www.combatlaw.org/v7i1.php

12. Ghai A. Disembodied form: issues of disabled women. Delhi: Haranand Publications; 2003.

13. Sengupta S.. No rights for the mentally disabled. Infochange news and features [Internet]. 2008 Apr [cited 2009 Nov 24].[about 3 screens]. Available from: //infochangeindia.org/200804117032/Disabilities/ Analysis/No-rights-for-the-mentally-disabled.html

* Amendment introduced vide Act No 64 of 2002 that though mental retardation may be incurable, the person has a fundamental right to be a part of the social mainstream. A mentally retarded woman above 18 years of age has the right to self-determination with regard to the continuation or otherwise of her pregnancy.

\title{
Right to human dignity
}

\section{UJJWALA MHATRE}

Centre for Enquiry into Health and Allied Themes, Survey No 2804 \&2805, Aaram Society Road, Vakola, Santacruz East, Mumbai 400055 INDIA email: ujjwalkiran@gmail.com

The Supreme Court (SC) judgment on the right of a mentally retarded woman to continue with her pregnancy (1) was the outcome of a petition filed in the apex court. This petition appealed against the order of the Punjab and Haryana $\mathrm{HC}$ to terminate the pregnancy of a woman who had been raped by staff at the government shelter, Nari Niketan, in Sector 26, Chandigarh where she was an inmate. The High Court had based its reasoning on the fact that the woman was an orphan suffering from mental retardation and would therefore, be unable to look after the child once it was born.

One of the arguments that the SC accepted, while reversing the $\mathrm{HC}$ judgement, was that the Medical Termination of Pregnancy Act did not permit a medical termination of pregnancy (MTP) to be performed on a mentally retarded (not mentally ill) woman who had attained the age of majority, without her consent. It also accepted the arguments of the advocate appearing in the SC that the woman wanted the child, was physically fit to bear the child and would be capable of looking after it with supervision. The Bench consisting of Chief Justice K G Balakrishnan and Justice P Sathasivam was confronted with this human rights issue in a special leave petition against an interim order of the Punjab and Haryana $\mathrm{HC}$ for immediate termination of the pregnancy. The Bench issued a notice to the Chandigarh administration, on whose petition the July 17, 2009, order was passed. It was argued that doctors did not form the opinion that termination of pregnancy was in the best interests of the girl, and that the medical report suggested that she required support and supervision to help her raise the child. The girl had expressed an unambiguous and unequivocal desire to keep the child. The petitioner argued that termination of pregnancy against the mother's wish was against the provisions of the MTP Act, 1971, and the Rights of the Disabled.

It is granted that a girl, even if mentally retarded, should not be deprived of the right to motherhood provided she is given proper support in fulfilling the tasks entailed. However, the condition in which the woman has been living, and will continue to live even after the birth of her child, does not suggest that she will have any such support system. Besides, this woman was a victim of sexual abuse by the institution's staff - the very people appointed for the inmates' welfare and security. What guarantee is there that this situation will change and that she as well as her child will not be targeted in a similar fashion in the future?

In fact the central issue in this case concerns the treatment of a destitute and vulnerable, mentally handicapped woman in a government-run institution. Medical experts have certified the woman's mental age to be just nine years. This makes the crime even more complicated and heinous. And what do we make of the fact that her pregnancy was not detected for more than two months even though an attendant is apparently assigned the duty of recording the menstrual cycles of all the inmates? This reflects gross negligence on the part of the staff assigned to look after the inmates.

One has to visit any of the shelter homes for women and children, institutions that are supposed to provide protection, care and training in skills that would enable them to earn their 
living if the need arose, to believe the dire state of affairs that prevails there. These may be homes for juvenile delinquents or destitute women, reform homes for women convicts or homes for the mentally retarded.

The lack of serious attention given to this issue by the media, in this particular case, suggests that we have started taking such incidents for granted. It is good that in this case, the lower court called for an inquiry into the conditions of such shelter homes, leading to an FIR being filed and interrogation of security guards from the institution. However, we have little reason to believe that things are going to change for the better and ample reason feel sorry for the inmates of these homes.

To give just one illustration, a report of the Delhi Commission for Protection of Child Rights states that inmates in government juvenile homes are living a life "worse than that of animals". Conditions of extraordinary filth, inadequate, ill-qualified staff, gross overcrowding - these are the normal situation in these institutions, as described in the commission's report following its inspection. The people housed in these buildings were unwashed and unclothed, sleeping on the floor, and eating inedible food. They suffered from numerous illnesses caused by overcrowding and unhygienic conditions. They were beaten often, they were kept locked up at night, the list goes on (2).

There has been much debate in the media about the right of a mentally retarded woman to motherhood. However, there has been a complete silence on what should be the central issues for all concerned - the safety and security of inmates in shelter homes, the guarantee of their human dignity, and compassion for these vulnerable and often neglected people. It is not the first time that the inhabitants of such homes have been exposed to such indignities. All the more reason therefore that there should have been a hue and cry about this serious lapse on the part of the authorities in providing protection to this most vulnerable section of society, whose guardianship is their responsibility. Yet, this is the state of affairs in most homes for the destitute, the disabled and delinquents. To make things worse, sectional legal battles tend to limit our vision regarding the fact that comprehensive justice -ensuring the mental physical, social and economic well-being of every individual and which is the right of every human being - is being denied to a vast section of the population in this, the world's largest democracy.

The second question is whether the woman under consideration was capable of giving her informed consent - for or against medical termination of pregnancy. Can her refusal to undergo an abortion, and her insistence on continuing the pregnancy to term, be considered valid given her mental age, her understanding of sexual relationships and the consequences for a child born as a result of sexual abuse, that too in a shelter home? The woman apparently described the child she was carrying as a toy she would like to play with.

Medical opinions with respect to this case suggest that a mentally disabled woman can successfully mother a child though she will need supervision to rear it and tend to its needs. The expert body appointed in this case had also opined that "She knows that she is bearing a child and is keen to have one." The same body also points out, however, that the woman is "unable to appreciate and understand the consequences of her own future and that of the child she is bearing". Will such a woman be able to contribute to the mental, emotional needs of the child as it grows up? For that matter, will she even be able to anticipate its physical needs?

Finally, is this really about the right to motherhood? This "right" is, more often than not, thrust upon women who, in a country like ours, have no control over their own sexuality and cannot decide whether or not to resort to contraception, whether or not to get pregnant, whether or not to have a baby, when to have children and how many to have. Even the decision to seek abortion is never that of women alone. The rights of disabled women and girls cannot be seen in isolation from this context.

The judgment sets a precedent while at the same time trying to change the stereotypes that society has constructed. However, many a good judgment fails to translate into a better quality of life for the person in whose favour it is passed. Similarly, unless the treatment meted out to mentally retarded persons by society undergoes a radical change, and social institutions meant for the welfare and security of destitute and disabled persons stop abusing their vulnerable inmates and adopt a sensitive attitude towards them, the fate of these people is not going to change.

\section{References}

1. Supreme Court of India. Judgments, the judgment information system of India. Civil appeal no.5845 of 2009.Supreme Court of India [Internet]. 2009 Aug 28 [cited 2009 Nov 20]. Available from: http://judis.nic.in/ supremecourt/imgs.aspx

2. Srinivasan S. Life interrupted - at Delhi's inhuman juvenile homes. IndoAsian News Service[Internet]. Bangkok (Thailand): Thaindian News; 2009 Jun 25 [cited 2010 Jan 14]. Available from: http://www.thaindian. com/newsportal/health/life-interrupted-at-delhis-inhuman-juvenilehomes-feature_100209302.html 